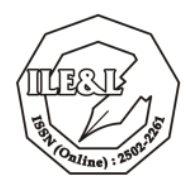

Journal Indonesian Language Education and Literature Vol. 2, No. 1, 2016 http://www.syekhnurjati.ac.id/jurnal/index.php/jeill/

\title{
ASPEK KOHESI DAN KOHERENSI DALAM PENULISAN KARANGAN DESKRIPSI YANG DISUSUN OLEH PEMBELAJAR BIPA (STUDI KASUS MAHASISWA THAMMASAT UNIVERSITY, BANGKOK PADA PROGRAM SEA-GATE UGM 2016)
}

\author{
Itaristanti \\ IAIN Syekh Nurjati Cirebon \\ itaristanti@yahoo.com
}

\begin{abstract}
Abstrak
Penelitian ini bertujuan untuk menyajikan hasil analisis terhadap aspek-aspek kohesi dan koherensi dalam penulisan paragraf deskripsi dalam bahasa Indonesia supaya tercipta paragraf yang padu bagi pembelajar asing atau pembelajar BIPA. Selain itu, penelitian ini juga bertujuan untuk menemukan teknik yang sesuai dalam pengajaran menulis karangan bagi pembelajar asing. Adapun metode yang digunakan adalahmetode kualitatif. Hasil penelitian menunjukkan bahwa kesalahan terbanyak adalah dalam penggunaan konjungsi.
\end{abstract}

Kata kunci: deskripsi, karangan, kohesi, koherensi, pembelajar BIPA

\begin{abstract}
The objective of this research is to present analysis toward several aspects in term of cohesion and coherence in writing paragraph of Indonesian language: in order to elaborate coherent paragraph for foreign learners or BIPA students. Other objective is to find the most suitable techniques for teaching essay writing for foreign learners. This research applies a qualitative method. The outcome of the research shows that the most common mistake is the use of conjunction.
\end{abstract}

Key words: cohesion, coherence, description, essay, BIPA students

\section{A. Pendahuluan}

Bahasa merupakan unsur yang sangat penting dalam kehidupan manusia. Dengan bahasalah, manusia dapat menyampaikan ide, pendapat, perasaan, dan pikirannya. Penyampaian ide, pendapat, perasaan, dan pikiran tersebut dapat disampaikan baik secara lisan maupun tertulis.

Cara penyampaian ide secara lisan dan tertulis tentunya memiliki perbedaan. Penyampaian ide secara lisan biasanya dilakukan dengan menggunakan kalimat yang lebih ringkas. Sementara itu, dalam ragam tulis, penyampaian ide dilakukan dengan kalimat yang lengkap. Unsur-unsur gramatikanya harus jelas. Selain itu, tanda baca pun harus tepat agar makna kalimat dapat ditangkap secara tepat. 


\section{Journal Indonesian Language Education and Literature Vol. 2, No. 1, 2016}

http://www.syekhnurjati.ac.id/jurnal/index.php/jeill/

Selain unsur-unsur pembentuk kalimat dan tanda baca yang digunakan harus tepat, aspek kepaduan paragraf pun harus betul-betul diperhatikan. Aspek kepaduan paragraf itu meliputi aspek kohesi dan koherensi. Antara bentuk kalimat yang satu dengan kalimat yang lain akan membentuk sebuah hubungan yang disebut dengan kohesi, sedangkan hubungan makna yang logis antara kalimat yang satu dengan yang lain disebut dengan koherensi.

Bagi pembelajar asing, memadukan aspek kohesi dan koherensi dalam penulisan karangan masih terlihat sulit. Pembelajar asing yang dimaksud dalam penelitian ini adalah orang dari negara lain yang sedang belajar bahasa Indonesia. Sebagai contoh, masih banyak penggunaan konjungsi yang tidak tepat dalam memadukan hubungan antarunsur dalam satu kalimat ataupun antarkalimat. Tentu saja, hal ini akan berpengaruh pada ketepatan makna atau ide yang akan disampaikan.

Karena hal itulah, penelitian ini kemudian dilakukan. Penelitian ini terfokus pada analisis terhadap karangan yang berjenis deskripsi. Adapun hal-hal yang akan dianalisis dalam penelitian ini di antaranya aspek kohesi gramatikal, aspek kohesi leksikal, dan hubungan kelogisan antarkalimat (aspek koherensi) dalam karangan deskripsi yang disusun oleh pembelajar asing.

Adapun tujuan dari penelitian ini yang pertama adalah ditemukannya aspek-aspek yang belum tepat tersebut agar dalam penulisan karangan selanjutnya dapat tercipta hasil yang kohesif dan kohenren. Dengan memperhatikan kedua unsur tersebut, kepaduan paragraf dapat terjaga sehingga ide yang akan disampaikan penulis secara tepat dapat diterima oleh pembaca.Tujuan yang kedua adalah ditemukannya teknik yang tepat dalam pengajaran penulisan karangan dalam bahasa Indonesia bagi pembelajar asing. Dengan demikian, pembelajar asing akan lebih memahami struktur lahir dan struktur batin kalimat dalam bahasa Indonesia. Dengan memahami kedua struktur tersebut, mereka akan lebih mudah dalam mengembangkan ide menjadi sebuah karangan yang padu.

\section{B. Metode Penelitian}

Metode yang digunakan dalam penelitian ini adalah metode kualitatif. Proses penelitian kualitatif melibatkan upaya-upaya penting, seperti mengajukan pertanyaanpertanyaan dan prosedur-prosedur, mengumpulkan data yang spesifik dari para 
Journal Indonesian Language Education and Literature vol. 2, No. 1, 2016

http://www.syekhnurjati.ac.id/jurnal/index.php/jeill/

partisipan, menganalisis data secara induktif mulai dari tema-tema yang khusus ke tematema yang umum, dan menafsirkan makna data (Creswell, 2014: 4).

Pengumpulan data dilakukan dengan pengambilan dokumen-dokumen kualitatif. Dalam penelitian ini, dokumen yang diambil adalah dokumen publik yang berupa karangan jenis deskripsi yang disusun oleh mahasiswa asing yang menjadi subjeknya. Karangan deskripsi berasal dari mahasiswa BIPA (Bahasa Indonesia untuk Penutur Asing) kelas Menulis yang terdiri atas tujuh orang. Mereka berasal dari Thailand. Mereka masuk dalam program SEA-Gate. SEA-Gate atau Southeast Asian Languages Programe merupakan sebuah program yang bertujuan memberikan pemahaman mengenai masyarakat dan budaya Asia Tenggara melalui bahasa yang diselenggarakan oleh Pusat Studi Sosial Asia Tenggara, Universitas Gadjah Mada. Setelah data terkumpul, tahap berikutnya adalah analisis data. Data yang berupa dokumen tersebut dibaca secara teliti, diidentifikasi unsur-unsur kohesi dan koherensinya, kemudian ditemukan generalisasinya. Hasil analisis data kemudian disajikan secara deskriptif.

\section{Hasil dan Pembahasan}

Sebuah karangan dikatakan utuh apabila mengandung aspek-aspek yang padu dan menyatu. Aspek-aspek yang membangun kepaduan karangan adalah aspek kohesi dan koherensi. Kohesi adalah hubungan yang padu antara bentuk kalimat yang satu dengan kalimat yang lain, sedangkan koherensi adalah hubungan yang logis atau hubungan makna antara kalimat yang satu dengan kalimat yang lain. Kohesi merupakan hubungan perkaitan antarproposisi yang dinyatakan secara eksplisit oleh unsur-unsur gramatikal dan semantik dalam kalimat-kalimat yang membentuk wacana (Alwi, dkk.: 427).

Kohesi terdiri dari kohesi gramatikal dan kohesi leksikal atau hubungan leksikal. Kohesi di dalam wacana tidak hanya ditentukan oleh adanya koreferensi, tetapi juga adanya hubungan leksikal. Halliday (1976:6) juga mengemukakan bahwa kohesi terdiri dari dua bagian, yaitu kohesi gramatikal (grammatical cohesion) dan kohesi leksikal (lexical cohesion). Aspek kohesi gramatikal terdiri dari referensi (reference), subtitusi (subtitution), elipsis (ellipsis), dan konjugsi (conjunction). Kohesi leksikal terdiri dari repetisi, sinonimi, antonimi, hiponimi, kolokasi, dan ekuivalensi.

\section{Kohesi Gramatikal}

\section{a. Referensi}




\section{Journal Indonesian Language Education and Literature Vol. 2, No. 1, 2016 http://www.syekhnurjati.ac.id/jurnal/index.php/jeill/}

Referensi adalah bagian dari kohesi gramatikal yang berhubungan dengan penggunaan kata atau kelompok kata untuk menunjuk kata atau kelompok kata yang lain. Menurut Sumarlam (2003:23), ada dua jenis referensi, yaitu: referensi endofora dan referensi eksofora.

Dikatakan mengandung referensi endofora apabila acuannya berada di dalam teks wacana, sedangkan referensi eksofora apabila acuannya di luar teks wacana. Referensi endofora dibedakan menjadi pengacuan anaforis dan pengacuan kataforis. Apabila satuan lingual tertentu mengacu pada satuan lingual lain yang mendahuluinya atau mengacu ke kiri disebut dengan pengacuan anaforis, sedangkan apabila satuan lingual tertentu mengacu pada satuan lingual lain yang mengikutinya atau mengacu ke kanan disebut dengan pengacuan kataforis.

Satuan-satuan lingual yang mengacu satuan lingual yang lain tersebut dapat berupa kata ganti orang (pronomina persona), kata ganti penunjuk (pronomina demonstratif), dan pengacuan komparatif. Pengacuan pronomina persona meliputi kata ganti orang pertama, kedua, dan ketiga, baik tunggal maupun jamak. Pengacuan pronomina demonstratif meliputi kata penunjuk waktu (temporal) dan kata penunjuk tempat (lokasional). Pengacuan komparatif membandingkan dua hal atau lebih yang mempunyai kemiripan dalam segi bentuk atau sifat.

Berikut ini beberapa contoh penggunaan unsur pengacuan yang tidak tepat dalam karangan deskripsi yang menjadi objek dalam penelitian ini.

1) Bali adalah sebuah provinsi di Indonesia. Ibu kota provinsi adalah Denpasar.

Dalam contoh 1) di atas terdapat dua kalimat. Kalimat pertama menyatakan bahwa Bali adalah sebuah provinsi di Indonesia. Penulis pada kalimat kedua ingin menyatakan bahwa ibukota provinsi Bali adalah Denpasar. Namun, penyampaian kalimatnya belum tepat. Seharusnya, setelah kata provinsi dibubuhkan kata tersebut supaya pengacuannya jelas.

1a) Bali adalah sebuah provinsi di Indonesia. Ibu kota provinsi tersebut adalah Denpasar.

Hal serupa juga terlihat pada contoh 2) berikut.

2) Kota Jakarta memiliki banyak tempat wisata seperti Taman Mini Indonesia indah merupakan suatu kawasan taman wisata bertema budaya indonesia di jakarta Timur. Area seluas kurang lebih 150 hektare. 
Subjek pada kalimat kedua contoh 2) belum tampak jelas. Kalimat Area seluas kurang lebih 150 hektare masih terasa janggal. Penulis seharusnya menambahkan frasa taman itu supaya subjek dan pengacuan/referennya jelas sehingga kalimatnya menjadi Area taman itu seluas kurang lebih 150 hektare. Kalimat tersebut juga dapat diubah menjadi Luas area taman itu kurang lebih 150 hektare. Kata itu merupakan kata penunjuk atau pronomina demonstratif yang dalam konteks ini menunjuk pada Taman Mini Indonesia Indah. Perbaikan kalimatnya dapat dilihat di bawah ini.

2a) Kota Jakarta memiliki banyak tempat wisata, seperti Taman Mini Indonesia Indah yang merupakan suatu kawasan taman wisata bertema budaya Indonesia di Jakarta Timur. Luas area taman itu kurang lebih 150 hektare.

Sama halnya dengan contoh 2), contoh 3) di bawah ini pun menjadi lebih jelas pengacuannya apabila ditambahkan kata penunjuk itu untuk menunjuk pada Kebun Binatang Ragunan.

3) Kebun Binatang Ragunan adalah sebuah kebun binatang yang terletak di daerah Ragunan, Pasar minggu, Jakarta, Indonesia. Kebun binatang seluas 140 hektare.

Kata itu seharusnya ditambahkan setelah kata binatang pada bagian kalimat yang kedua sehingga menjadi Kebun binatang itu seluas 140 hektare. Kalimat tersebut juga dapat diubah menjadi Luas kebun binatang itu adalah 140 hektare. Dengan demikian, unsur subjek dan predikatnya jelas. Jika subjek dan predikatnya jelas, ide yang ingin disampaikan pun tepat diterima oleh pembaca.

\section{b. Substitusi}

Subtitusi adalah salah satu unsur kohesi gramatikal yang berupa penggantian satuan lingual tertentu dengan satuan lingual yang lain di dalam sebuah karangan atau wacana. Substitusi terdiri dari substitusi nomina, substitusi verba, substitusi frasa, dan substitusi klausa.

Substitusi nomina adalah penggantian satuan lingual yang berkategori nomina. Substitusi verba adalah penggantian satuan lingual yang berkategori verba. Substitusi frasa adalah penggantian satuan lingual tertentu yang berupa kata atau frasa dengan satuan lingual lain yang berupa frasa. Substitusi klausa adalah 
penggantian satuan lingual tertentu yang berupa klausa atau kalimat dengan satuan lingual lain yang berupa kata atau frasa.

Pada kalimat kedua dalam contoh 4) berikut, penulis sebenarnya ingin menyampaikan bahwa ada enam perguruan tinggi di kota yang disebut pada kalimat sebelumnya.

4) ... Selain itu, kota ini menjadi pusat pendidikan dan kesehatan karena ada perguruan tinggi dan fasilitas kesehatan. Terdapat enam perguruan tinggi di antaranya merupakan perguruan tinggi milik pemerintah.

Pernyataan adanya enam perguruan tinggi pada kalimat kedua berkaitan dengan pernyataan pada kalimat pertama. Kalimat pertama menyatakan bahwa kota yang dimaksud juga menjadi pusat pendidikan. Akan tetapi, untuk menghubungkan kedua pernyataan itu, penulis karangan deskripsi tersebut tidak menyisipkan frasa depan yang dapat menjadi unsur pembangun kepaduan bentuk antarkalimatnya. Unsur yang dimaksud adalah unsur substitusi di sana. Frasa depan di sana seharusnya disisipkan setelah frasa perguruan tinggi sehingga kalimatnya menjadi Terdapat enam perguruan tinggi di sana, di antaranya merupakan perguruan tinggi milik pemerintah. Frasa depan di sana menggantikan sekaligus menunjuk pada kota yang dimaksud oleh penulis dalam kalimat tersebut.

5) ... Sistem ini akan tetap kuat dan berlaku dalam masyarakat Minangkabau sampai sekarang, dia tidak akan mengalami evolusi sehingga menjadisistem patrilineal.

Berbeda dengan contoh 4) yang tidak ada unsur yang menjadi substitusinya, pada contoh 5) di atas terdapat unsur yang menjadi substitusi, tetapi tidak tepat. Unsur tersebut adalah pronomina dia. Pronomina dia menjadi unsur substitusi bagi sistem yang dimaksud pada pernyataan sebelumnya. Pronomina dia lebih tepat digunakan untuk menyubstitusi orang. Kalimat 5) dapat diubah supaya lebih efektif menjadiSistem ini akan tetap kuat dan berlaku dalam masyarakat Minangkabau sampai sekarangdantidak akan mengalami evolusi menjadi sistem patrilineal. Konjungsi sehingga juga tidak tepat penggunaannya sehingga dengan melesapkannya akan membuat ide kalimat menjadi lebih jelas.

6) Masyarakat Jakarta memiliki karakteristik sedikit berbeda dengan masyarakat di kota lain. Masyarakat atau orang Jakarta berasal dari berbagai daerah di Indonesia. 


\section{Journal Indonesian Language Education and Literature Vol. 2, No. 1, 2016}

http://www.syekhnurjati.ac.id/jurnal/index.php/jeill/

Pada kalimat pertama contoh 6) di atas, frasa masyarakat Jakarta diulang kembali pada kalimat yang kedua. Supayalebihefektif, frasamasyarakatatau orang Jakartapadakalimatkeduatersebutseharusnyadisubstitusidenganpronominamereka sehinggakalimatnya menjadi:

6a) Masyarakat Jakarta memiliki karakteristik sedikit berbeda dengan masyarakat di kota lain. Mereka berasal dari berbagai daerah di Indonesia.

\section{c. Elipsis}

Elipsis atau pelesapan adalah salah satu unsur kohesi gramatikal yang berupa pelesapan atau penghilangan satuan lingual tertentu yang telah disebutkan sebelumnya. Satuan lingual yang dilesapkan tersebut dapat berupa kata, frasa, klausa, atau kalimat.

Berdasarkan hasil analisis, dalam penulisan karangan deskripsi, pembelajar asing tidak mengalami kesulitan dalam penggunaan unsur yang dapat dilesapkan, misalnya terlihat dalam contoh 7) dan 8) berikut.

7) Di Jakarta ada banyak orang yang berasal dari berbagai suku, misalnya Jawa, Batak (dari Medan di pulau Sumatra), Sunda, Tionghoa dan Betawi.

Kata suku tidak disebutkan kembali pada suku Jawa, Batak, Sunda, Tionghoa, dan Betawi. Kata suku cukup disebutkan satu kali pada pernyataan sebelumnya. Begitu pula dengan contoh 8). Kata bahasa dalam rincian hanya melekat pada nama Komering. Selanjutnya, kata bahasa mengalami proses elipsis pada rincian-rincian berikutnya.

8) Namun para pendatang seringkali menggunakan bahasa daerahnya sebagai bahasa sehari-hari, seperti bahasa Komering, Rawas, Musi, Pasemah, dan Semendo.

Elipsis memiliki beberapa fungsi, antara lain: untuk menghasilkan kalimat yang efektif, mencapai nilai efisien, mencapai kepaduan wacana dan kepraktisan berbahasa terutama dalam komunikasi lisan.

\section{d. Konjungsi}

Konjungsi merupakan unsur kohesi gramatikal yang menghubungkan satuan lingual yang satu dengan satuan lingual yang lain di dalam sebuah karangan atau wacana. Konjungsi disebut juga dengan konjungtor atau kata sambung (Alwi, 2003:296). Unsur yang dirangkaikan dapat berupa kata, frasa, klausa, dan kalimat.

9) Terdapat enam perguruan tinggi di antaranya merupakan perguruan tinggi milik pemerintah. Dan ada perpustakaan di daerah Sumatera Barat yang 
Journal Indonesian Language Education and Literature vol. 2, No. 1, 2016

http://www.syekhnurjati.ac.id/jurnal/index.php/jeill/

terletak di kota Padang yang termasuk salah satu perpustakaan terbaik di Indonesia.

Dalam kalimat nomor 9) di atas, terdapat konjungsi koordinatif dan. Konjungsi tersebut digunakan untuk menghubungkan unsur-unsur satuan lingual dalam satu kalimat dan merupakan penanda penambahan. Sementara itu, yang tampak pada contoh tersebut, konjungsi dan digunakanuntuk menghubungkan antarkalimat. Hal ini tidaklah tepat. Kalimat 9) seharusnya diperbaiki menjadi:

9a) Terdapat enam perguruan tinggi di Sumatera Barat, di antaranya merupakan perguruan tinggi milik pemerintah dan perpustakaan yang terletak di Kota Padang yang termasuk salah satu perpustakaan terbaik di Indonesia.

Selain penggunaan konjungsi dan perlu diperbaiki, namaSumatera Barat lebih tepat diletakkan setelah frasa perguruan tinggi supaya ide kalimatnya semakin jelas. Kata daerah pun yang sebelumnya melekat pada nama Sumatera Barat perlu dilesapkan supaya lebih efektif.

Sementara itu, tipe kesalahan penggunaan konjungsi pada contoh berikut sedikit berbeda dengan contoh 9). Dalam kalimat 10) terdapat konjungsi antarkalimat namun. Konjungsi ini menghubungkan satu kalimat dengan kalimat yang lain dan menyatakan pertentangan dengan keadaan sebelumnya. Penggunaanya sudah tepat, hanya saja perlu dibubuhkan tanda baca koma.

10) Penduduk Palembang merupakan etnis Melayu dan menggunakan Bahasa Melayu yang telah disesuaikan dengan dialek setempat yang kini dikenal sebagai Bahasa Palembang. Namun para pendatang seringkali menggunakan bahasa daerahnya sebagai bahasa sehari-hari, seperti bahasa Komering, Rawas, Musi, Pasemah, dan Semendo. Namun agama mayoritas di Palembang adalah Islam.

Selain konjungsi namun pada kalimat kedua, terdapat konjungsi namun pada kalimat ketiga. Akan tetapi, penggunaan konjungsi tersebut tidaklah tepat karena kalimat sebelumnya menyatakan perbedaan penggunaan bahasa, sedangankan dalam kalimat ketiga menyatakan agama. Hal tersebut merupakan dua hal yang berbeda yang secara logika tidak dapat dipertentangkan. Tidak ada hubungan antara penggunaan bahasa dan kepemelukan agama dalam pernyataan itu. Sebaiknya, kalimat ketika dijadikan pembuka bagi paragraf baru dan konjungsi namun dihilangkan. 
Journal Indonesian Language Education and Literature vol. 2, No. 1, 2016

http://www.syekhnurjati.ac.id/jurnal/index.php/jeill/

Tipe kesalahan berikutnya dalam penggunaan konjungsi adalah penggunaannya yang berulang kali dalam satu kalimat, seperti tampak pada kalimat 11) berikut.

11)... Di dalamnya, terdapat berbagai koleksi yang terdiri dari 295 spesies dan 4040 spesimen, dan Taman Impian Jaya Ancol ...

Konjungsi dan seharusnya tidak digunakan sebelum nama Taman Impian Jaya Ancol. Selain penggunaannya yang berulang kali, penggunaan tersebut tidak tepat karena penyebutan nama Taman Impian Jaya Ancol pasti akan digunakan penulisnya untuk membahas hal yang lain yang berbeda dengan pernyataan sebelumnya. Penulis dapat memulainya tanpa menggunakan konjungsi dan atau dengan menggunakan konjungsi lain yang lebih tepat.

Berbeda dengan dan yang termasuk dalam konjungsi koordinatif, konjungsi sehingga termasuk dalam jeniskonjungsi subordinatif. Konjungsi subordinatif digunakan untuk menghubungkan dua klausa atau lebih yang tidak memiliki unsur sintaktis yang sama. Konjungsi tersebut digunakan dalam satu kalimat. Dengan demikian, penggunaan konjugsi sehingga dalam contoh 12) berikut tidak tepat.

12) Wilayahnya berbatasan dengan Selat Madura di sebelah utara dan timur, kabupaten Sidoarjo di sebelah selatan, serta Kabupaten Gresik di sebelah barat. Sehingga, Surabaya juga merupakan pusat bisnis, perdagangan, industri dan pendidikan.

Jika dilihat dari segi makna, konjungsi tersebut menyatakan hasil. Penggunaannya seharusnya tidak mendahului sebuah kalimat. Contoh 12) dapat diubah menjadi:

12a) Wilayahnya berbatasan dengan Selat Madura di sebelah utara dan timur, Kabupaten Sidoarjo di sebelah selatan, serta Kabupaten Gresik di sebelah barat sehingga Surabaya menjadi pusat bisnis, perdagangan, industri dan pendidikan.

Kata juga dan merupakan diganti dengan kata menjadi supaya ide kalimat yang terkandung di dalamnya semakin jelas.

Ketidaktepatan konjungsi berikutnya adalah penggunaan kata tetapi dalam contoh 130 berikut ini. Dalam contoh tersebut terdapat dua kalimat yang utuh. Untukmenghubungkannyadiperlukan konjungsi antarkalimat yang tepat. Konjungsi antarkalimat yang tepat adalah akan tetapi atau namun. 
Journal Indonesian Language Education and Literature vol. 2, No. 1, 2016

http://www.syekhnurjati.ac.id/jurnal/index.php/jeill/

13) Cara berbicara dan kehidupan sehari-hari orang Surabaya lebih cepat dari orang Yogyakarta. Tetapi, orang Surabaya sama ramahnya dengan orang Yogyakarta.

Kalimat 13) tersebut harus diubah menjadi:

13a) Cara berbicara dan kehidupan sehari-hari orang Surabaya lebih cepat dari orang Yogyakarta. Akan tetapi, mereka sama ramahnya dengan orang Yogyakarta.

Frasa orang Surabaya setelah konjungsi tetapi dapat disubstitusi dengan pronomina orang ketiga jamak, yaitu mereka.

\section{Kohesi Leksikal}

\section{a. Repetisi}

Repetisi adalah salah satu unsur dalam kohesi leksikal yang berupa pengulangan satuan lingual yang berupa suku kata, kata, atau bagian kalimat yang dianggap penting untuk memberikan tekanan dalam sebuah konteks. Ada delapan jenis repetisi yang dikelompokkan berdasarkan tempat satuan lingual yang diulang dalam baris, yaitu: epizeukis, tautotes, anafora, epistrova, simploke, mesodiplosis, epanalepsis, dan anadiplosis (Keraf, 2007:127-129). Akan tetapi, dalam karangan yang dijadikan objek dalam penelitian ini, penggunaan unsur repetisi masih belum tepat, misalnya dalam kalimat 14) di bawah ini.

14) Kota Semarang memiliki banyak tempat wisata di kota Semarang seperti Monumen Tugu Muda yang dibuat untuk mengingat pahlawan.

Pengulangan Kota Semarang di atas menjadikan kalimat justru semakin tidak efektif, padahal tujuan pengulangan adalah memberikan penekanan pada unsur yang dianggap penting. Pengulangan seperti halnya pada kalimat 14) melanggar prinsip kehematan kata. Kalimat tersebut harus diubah menjadi:

14a) Kota Semarang memiliki banyak tempat wisata, seperti Monumen Tugu Muda yang dibuat untuk mengingat pahlawan.

Selain ketidaktepatan unsur repetisi, kelogisan makna kalimat juga wajib dipertimbangkan. Jika dalam kalimat itu disebutkan memiliki banyak tempat wisata, seharusnya rincian contoh tempat wisatanya tidak hanya satu. Dengan demikian, contoh yang banyak akan mendukung pernyataan bahwa Kota Semarang memang memilik banyak tempat wisata. 


\section{Journal Indonesian Language Education and Literature Vol. 2, No. 1, 2016}

http://www.syekhnurjati.ac.id/jurnal/index.php/jeill/

Selain contoh 14), ada pula contoh unsur repetisi yang kurang tepat, yaitu pada kalimat di bawah ini.

15) Tugu Pahlawan adalah sebuah monumen yang menjadi monumen di kota Surabaya.

Kata monumen diulang dua kali untuk menjelaskan Tugu Pahlawan. Namun, pengulangan tersebut membuat bentuk kalimat tidak kohesif. Kata monumen berarti bangunan atau tempat yang mempunyai nilai sejarah yang penting dan karena itu dipelihara dan dilindungi negara (KBBI, 1995: 665). Dengan merujuk pada pengertian tersebut, kalimat 15) dapat diperbaiki menjadi:

15a) Tugu Pahlawan adalah sebuah bangunan yang menjadi monumen di Kota Surabaya.

\section{b. Sinonimi}

Sinonimi adalah bentuk bahasa yang maknanya mirip atau sama dengan bentuk lain; kesamaan itu berlaku bagi kata, kelompok kata, atau kalimat, walaupun umumnya yang dianggap sinonim hanyalah kata-kata saja (Kridalaksana, 1983:154). Sinonim termasuk dalam kohesi leksikal yang mendukung kepaduan sebuah wacana. Sinonim berfungsi menjalin hubungan makna yang sepadan antara satuan lingual tetentu dengan satuan lingual yang lain dalam sebuah wacana.

16) Tujuannya adalah memberi persembahan atau bekal kepada leluhurnya yang turun pada hari raya Galungan.

17) Rumah ini sengaja dibangun dengan ruang kecil atau sempit untuk menahan suhu dingin dari pegunungan Papua.

Dalam konteks kalimat 16), kata persembahan maknanya mirip dengan kata bekal. Kata persembahan berarti 'pemberian atau yang dihidangkan' (KBBI, 1995: 904), sedangkan kata bekal berarti 'sesuatu yang disediakan' (KBBI, 1995: 106). Hanya saja, konteks pemakaian kata bekal harus dibedakan dengan kata persembahan. Persembahan itu ditujukan kepada yang dihormati.Sementara itu, pada contoh 17), kata kecil dalam konteks kalimat tersebut maknanya mirip dengan kata sempit. Kata kecil berarti 'kurang besar' (KBBI, 1995: 459) dan kata sempit berarti ‘tidak luas atau tidak lebar' (KBBI, 1995: 908). 


\section{Journal Indonesian Language Education and Literature Vol. 2, No. 1, 2016}

http://www.syekhnurjati.ac.id/jurnal/index.php/jeill/

Kesalahan lain yang perlu diperbaiki dalam kedua contoh di atas adalah penulisan huruf. Nama hari raya dan nama geografi seharusnya diawali dengan huruf kapital. Perbaikan tersebut dapat diamati di bawah ini.

16a) Tujuannya adalah memberi persembahan atau bekal kepada leluhurnya yang turun pada Hari Raya Galungan.

17a) Rumah ini sengaja dibangun dengan ruang kecil atau sempit untuk menahan suhu dingin dari Pegunungan Papua.

\section{c. Antonimi}

Antonimi adalah dua kata atau lebih yang maknanya berlawanan (Kridalaksana, 1983:13). Antonim disebut juga dengan oposisi makna. Oposisi makna dapat dibedakan menjadi lima berdasarkan sifatnya. Kelima macam itu antara lain: oposisi mutlak, oposisi kutub, oposisi hubungan, oposisi hierarkial, dan oposisi majemuk. Oposisi makna atau antonim termasuk dalam kohesi leksikal.

18) Masjid raya sumatera barat merupakan salah satu bentuk modernisasi arsitektur tradisional di kota Padang.

Kata modernisasi berarti 'proses pergeseran sikap dan mentalitas sebagai warga masyarakat untuk dapat hidup sesuai dengan tuntutan masa kini' (KBBI, 1995: 662). Makna tersebut berlawanan dengan kata tradisional yang berarti 'menurut tradisi atau adat kebiasaan yang turun-temurun dari nenek moyang' (KBBI, 1995: 1069). Maksud dari kalimat 18) adalah bangunan Masjid Raya Sumatera Barat saat ini sudah berubah dari yang dulunya masih tradisional menjadi modern.

Ketidaktepatan yang lain dalam kalimat 18) adalah penulisan nama geografi masjid raya sumatera barat dan kota padang yang seharusnya ditulis dengan huruf kapital menjadi Masjid Raya Sumatera Barat dan Kota Padang.

\section{d. Hiponimi}

Hiponimi adalah hubungan antara makna spesifik dan makna generik (Kridalaksana, 2011:83). Hiponimi juga dapat diartikan sebagai satuan bahasa yaitu kata, frasa, atau kalimat yang maknanya dianggap merupakan bagian dari makna satuan lingual yang lain (Sumarlam, 2003:45). Satuan lingual yang mencakupi 
Journal Indonesian Language Education and Literature vol. 2, No. 1, 2016

http://www.syekhnurjati.ac.id/jurnal/index.php/jeill/

beberapa unsur atau satuan lingual yang berhiponim itu disebut dengan hipernim atau superordinat.

Hiponimi termasuk dalam kohesi leksikal. Fungsi hiponimi adalah untuk mengikat hubungan antarunsur atau antarsatuan lingual dalam wacana secara semantis atau untuk menjalin hubungan makna atasan dan bawahan.

19) Rujak cingur biasanya terdiri dari irisan beberapa jenis, timun, bengkuang, mangga muda, nanas dan kedondong.

Pada kalimat di atas, terdapat beberapa rincian kata yang bermakna spesifik, yaitu timun, bengkuang, mangga muda, nanas, dan kedondong. Namun, kata yang bermakna generik tidak dimunculkan. Supaya ide kalimat semakin jelas, seharusnya hipernim atau kata yang bermakna genariknya dimunculkan. Kata yang dimaksud adalah kata buah sehingga kalimat tersebut menjadi:

19a) Rujak cingur biasanya terdiri dari irisan beberapa jenis buah, antara lain timun, bengkuang, mangga muda, nanas, dan kedondong.

Selain buah, katayang perlu ditambahkan adalah antara lain yang berfungsi sebagai penegas adanya rincian. Tanda koma pun perlu dibubuhkan sebelum rincian yang terakhir, yaitu sebelum konjungsi dan.Tanda tersebut digunakan untuk memperjelas bahwa rincian yang dimaksud ada lima.

\section{e. Kolokasi}

Kolokasi disebut juga dengan sanding kata. Kolokasi adalah seluruh kemungkinan adanya beberapa kata dalam lingkungan yang sama; asosiasi yang tetap antara kata dengan kata-kata tertentu yang lain (Kridalaksana, 1983:87). Katakata yang berkolokasi adalah kata-kata yang cenderung dipakai dalam satu domain atau jaringan tertentu, misalnya dalam ranah pendidikan terdapat kata guru, murid, sekolah, dan lain-lain. Kolokasi termasuk dalam kohesi leksikal. Kata-kata yang berkolokasi akan mendukung kepaduan topik wacana.

20) Sistem kekerabatan di Padang seperti suku dibentuk menurut garis ibu, tiap-tiap orang diharuskan kawin dengan orang luar suku dan perkawinan bersifat matrilokal yaitu suami mengunjungi rumah istri.

Kata suami pada kalimat 20) berada dalam lingkungan yang sama dengan kata istri. Kedua kata tersebut berada dalam lingkungan hubungan kekerabatan. 
Journal Indonesian Language Education and Literature vol. 2, No. 1, 2016

http://www.syekhnurjati.ac.id/jurnal/index.php/jeill/

Dalam contoh tersebut, penggunaan kata yang berkolokasi sudah tepat. Namun, masih ada beberapa kesalahan, misalnya dalam tanda baca. Tanda baca koma seharusnya dibubuhkan setelah nama geografi Padang.

Selain itu, ada dua ide dalam contoh 20). Yang pertama adalah sistem kekerabatan yang dibentuk oleh garis ibu. Yang kedua adalah keharusan menikah dengan orang dari luar suku. Supaya ide kalimat menjadi semakin jelas, kalimat 20) harus dipecah menjadi dua, yaitu:

20a) Sistem kekerabatan di Padang, seperti suku dibentuk menurut garis keturunan ibu.Tiap-tiap orang diharuskan kawin dengan orang luar suku dan perkawinan tersebut bersifat matrilokal, yaitu suamimenetap di rumah istri.

Kata kekerabatan juga perlu ditambahkan setelah kata garis untuk memperjelas makna dan kata tersebut ditambahkansetelah kataperkawinan untuk memperjelas penunjukkan. Selain itu, pengertian sistem matrilokal juga perlu diperbaiki. Matrilokal adalah kebiasaan yang menentukan bahwa pengantin menetap di sekitar pusat kediaman kaum kerabat istri (KBBI, 1985: 638).

\section{f. Ekuivalensi}

Ekuivalensi disebut juga dengan kesepadanan. Ekuivalensi adalah hubungan kesepadanan antara satuan lingual tertentu dengan satuan lingual yang lain (Sumarlam, 2005:46). Sejumlah kata hasil proses afiksasi dari morfem asal yang sama menunjukkan adanya hubungan kesepadanan.

21) Disebut dengan rumah kebaya dikarenakan bentuk atapnya yang menyerupai pelana yang dilipat dan apabila dilihat dari samping maka lipatan-lipatan tersebut terlihat seperti lipatan kebaya.

Dalam kalimat 21), terdapat kata dilipat dan lipatan. Kedua kata tersebut berasal dari morfem bebas yang sama, yaitu lipat. Yang pertama mendapat awalan $d i$ - dan yang kedua mendapat akhiran - an. Kata dilipat merupakan bentuk pasif dari melipat yang berarti dapat dirangkap, sedangkan kata lipatanberarti 'hasil lipatan'(KBBI, 1995: 597). Selain itu, kata yang sebelum kata menyerupai sebaiknya dihilangkan supaya kalimat semakin efektif. Perbaikannya menjadi:

21a) Disebut dengan rumah kebaya dikarenakan bentuk atapnya menyerupai pelana yang dilipat dan apabila dilihat dari samping maka lipatanlipatan tersebut terlihat seperti lipatan kebaya. 
Journal Indonesian Language Education and Literature Vol. 2, No. 1, 2016

http://www.syekhnurjati.ac.id/jurnal/index.php/jeill/

\section{Koherensi}

Koherensi merupakan hubungan yang logis antara kalimat yang satu dengan kalimat yang lain dalam sebuah karangan atau wacana. Beberapa contoh hubungan yang tidak koheren dalam karangan deskripsi yang dijadikan objek dalam penelitian ini, di antaranya:

22) Selalu masyarakat dunia suddahmenggenaltentang budaya Bali terutama tarian Bali contohnya, Legong tarian. Legong tarian adalah tarian dari Bali yang gerakan rumit jari, gerak kaki yang rumit, dan gerak tubuh yang ekspresif dan ekspresi wajah.

Kehadiran kata selalu membuat kalimat 22) tidak logis. Makna kalimat menjadi kacau sehingga kata tersebut harus dihilangkan. Selain itu, terdapat kata yang ditulis dengan huruf ganda, misalnya suddah dan menggenal yang seharusnya ditulis dengan sudah dan mengenal.Supaya lebih efektif, kata tentang dapat dilesapkan.

Pola frasa pun tampak ada yang salah, misalnya Legongtarian yang seharusnya adalah tarian Legong, rumit jari yang seharusnya jari yang rumit. Ketidaktepatan makna juga terjadi karena munculnya frasa ekspresi wajah di bagian akhir kalimat. Kemungkinan, penulis kalimat tersebut masih akan menjelaskan ekspresi wajah yang seperti apa dalam tari Legong itu. Kalimat 220 dapat diperbaiki menjadi:

22a) Masyarakat dunia sudah mengenal budaya Bali terutama tarian Bali, misalnyatari Legong. Tari Legong adalah tarian dari Bali yang gerakan jari dan kakinya rumit serta gerak tubuhnya yang ekspresif.

Ketidaklogisan juga terlihat pada contoh di bawah ini. Pada kalimat 23) berikut, terdapat kata membakar. Jelas yang dimaksud adalah bebek atau ayamnya yang dibakar. Namun, dengan penggunaan kata membakar, makna kalimat menjadi kacau. Supaya logis dan jelas bahwa yang dibakar adalah bebek atau ayam maka bentuk kata yang tadinya berdiatesis aktif harus diubah menjadi pasif, yaitu dibakar. Hal serupa terjadi juga pada kata memanggang yang harus diubah menjadi dipanggang.

23) Bebek dan Ayam Betutu adalah nasi disajinkan dengan bebek atau ayam bahan dengan rempah-rempah lalu membakar berjam-jam. Nasi ayam dan Nasi Cambur adalah nasi putih disajinkan dengan ayam, banyak bahan 
Journal Indonesian Language Education and Literature vol. 2, No. 1, 2016

http://www.syekhnurjati.ac.id/jurnal/index.php/jeill/

dan sambal. Babi guling adalah daging babi memanggang untuk rempahrempah dan sayuran.

Selain itu, katayang harus ditambahkan di antara kata nasi dan kata disajikan. Kata disajinkan dan cambur di bawah ini salah sehingga harus diperbaiki pula. Nama makanan pun tidak perlu diawali dengan huruf kapital jika tidak berada di awal kalimat. Kata nasi ditambahkan di awal kalimat supaya memperjelas pengertian. Konjungsi antarkalimat sementara itu ditambahkan antara kalimat kedua dengan kalimat ketiga. Perbaikan kalimat 23) dapat diamati pada 23a) di bawah ini.

23a) Nasi bebek dan ayam betutu adalah nasi yang disajikan dengan bebek atau ayam yang dibakar berjam-jam dengan rempah-rempah. Nasi ayam dan nasi campur adalah nasi putih yang disajikan dengan ayam dan sambal. Sementara itu, babi guling adalah daging babi yang dipanggang dengan rempah-rempah dan sayuran.

Sama seperti contoh 22), kalimat 24) berikut ini salah pola frasanya, yaitu pada frasa cantik luat. Pola frasa tersebut terbalik.Kata luat pun salah. Yang benar adalah laut. Terbaliknya pola frasa menjadikan kalimat tidak koheren.

24) Saat ini Bali ada banyak wisata. Masyarakat dunia datang ke Bali karena Bali ada banyak cantik luat dan pantai contohnya, Pantai Nusa Dua, Pantai Sanur, Pantai Jimbaran dan Pantai Pandawa. Selain cantik luat dan Pantai Bali juga ada banyak candi karena agama di Bali adalah Hindu contohnya, Candi Uluwatu, Candi tebing Tegallinggah, Pura tirta Empul, Pura Besakih, Pura Ulan Danu Batur dan Pura Tanah Lot.

Karena konteks kalimat tersebut membahas tentang pariwisata, istilah yang sesuai adalah pantai, bukan laut sehingga dapat diperbaiki menjadi:

24a) Saat ini, di Bali terdapat banyak tempat wisata. Masyarakat dunia datang ke Bali karena di sana terdapat banyak pantai yang cantik, contohnya Pantai Nusa Dua, Pantai Sanur, Pantai Jimbaran, dan Pantai Pandawa. Selain itu, di sana juga banyak candi karena agama di Bali adalah Hindu,misalnya Candi Uluwatu, Candi Tebing Tegallinggah, Pura Tirta Empul, Pura Besakih, Pura Ulan Danu Batur, dan Pura Tanah Lot.

Demikian beberapa analisis penanda kohesi dan koherensi dalam karangan deskripsi yang disusun oleh pembelajar asing. Selain terhadap unsur kohesi dan koherensi, analisis juga dilakukan terhadap kesalahan dalam berbahasa, yang meliputi ketidaktepatan tanda baca, penggunaan kata, dan penggunaan huruf kapital. 
Journal Indonesian Language Education and Literature vol. 2, No. 1, 2016

http://www.syekhnurjati.ac.id/jurnal/index.php/jeill/

\section{Simpulan}

Berdasarkan hasil analisis terhadap karangan deskripsi yang disusun oleh pembelajar asing yang dijadikan objek dalam penelitian ini, dapat diambil beberapa simpulan seperti berikut ini.

1. Kesalahan terbanyak adalah penggunaan unsur konjungsi yang meliputi konjungsi dan, namun, sehingga, dan tetapi. Para pembelajar asing masih mengalami kebingungan dalam penentuan jenis konjungsi dan penempatannya. Sebagai contoh, konjungsi dandan tetapi yang termasuk dalam konjungsi koordinatif. Konjungsi sehingga termasuk jenis konjungsi subordinatif. Penggunaan konjungsi, baik korelatif maupun subordinatif, berada dalam satu kalimat. Berbeda dengan konjungsi namun yang menghubungkan antara kalimat yang satu dengan kalimat yang lain.

2. Pembelajar asing idak menemui kesulitan dalam penggunaan kata yang mempunyai hubungan antonimi, kolokasi, dan ekuivalensi. Dalam pelesapan kata/elipsis pun tidak terdapat kesalahan.

3. Pembelajar asing masih kurang memahami pola frasa dalam bahasa Indonesia, misalnya Legong tarian.

4. Bentuk diatesis aktif dengan pasif perlu ditekankan.

5. Kesalahan berbahasa lain yang sering muncul adalah ketidaktepatan penggunaan tanda baca dan huruf kapital.

Berdasarkan kesalahan-kesalahan yang sudah peneliti jelaskan, teknik yang tepat dalam mengajarkan menulis bagi pembelajar asing sebaiknya disesuaikan dengan levelnya. Untuk level pemula, media gambar layak dipertimbangkan sebagai alternatif model pembelajaran untuk merangsang timbulnya ide dalam menulis deskripsi. Untuk level lanjut, pengajar sebaiknya segera memberikan konsep-konsep yang terkait dengan substansi materi.

\section{Daftar Pustaka}

Alwi, Hasan, dkk. 2003. Tata Bahasa Baku Bahasa Indonesia. Jakarta: Balai Pustaka.

Creswell, John W. 2009. Research Design: Qualitative, Quantitative, and Mixed Methods Approaches. California: Sage Publications. 
Journal Indonesian Language Education and Literature Vol. 2, No. 1, 2016

http://www.syekhnurjati.ac.id/jurnal/index.php/jeill/

Halliday, MAK dan Ruqaiya Hasan. 1976. Cohesion in English.London: Edward Arnold.

Kridalaksana, Harimurti. 2011. Kamus Linguistik. Edisi Keempat. Jakarta: Gramedia.

Sumarlam. 2003. Analisis Wacana: Teori dan Praktik. Surakarta: Pustaka Cakra.

Tim Penyusun. 1995. Kamus Besar Bahasa Indonesia. Jakarta: Balai Pustaka. 